\title{
социолОГИЯ
}

УДК $352.075 .2 ; 321.728 ; 321.014$

DOI: $10.17223 / 1998863 X / 40 / 20$

\author{
A. Bordovskikh., R. Boussier
}

\section{AN EFFICIENT AND EFFECTIVE DEMOCRACY AT THE LOCAL LEVEL: NEW ALTERNATIVES TO POLICY NETWORKS ${ }^{1}$}

\begin{abstract}
Policy networks are believed to be one of the most suitable modern solutions to revitalize democracy, especially at the local level. Though, some scholars warn against their lack of democratic legitimacy and accountability. We share this position and question the networks commonly believed efficiency. We support our thesis with an analysis of several recent local infrastructure projects involving networks. The paper also explores some alternatives to policy networks. New forms of direct democracy, drawing inspiration from game theory and behavioral economy seem the most promising.

Key words: democracy effectiveness, democratic input and output, policy networks, participatory democracy, local democracy, decision-making process, preferential voting, infrastructure governance.
\end{abstract}

\section{Introduction}

The "troubled relationship" between democratic legitimacy and government efficiency lies at the heart of the crisis of democracy [1]. The potential conflict between these equally important terms $[2 ; 3]$ is a major challenge threatening the very existence of democracy.

In this respect, local democracy faces a dangerous paradox. On one hand, strengthening local democracy - through decentralization, devolution or subsidiarity - is viewed as one of the potential solutions to revive ailing democracies and to reconcile disenchanted citizens with res publica (the public thing). A recent poll, for example, in France showed that nearly $2 / 3$ of respondents think democracy is in crisis and $69 \%$ consider that giving more power to local bodies will improve the situation [4]. But on the other hand, local democracy seems to be acutely affected by a simultaneous loss of democratic effectiveness and efficiency. First is namely confirmed by an abysmal voter turnout at local elections in nearly all countries. As to efficiency reflected in government's ability to deliver public services, it also comes into question, considering the general difficulty to deliver key projects and services corresponding to citizens' preferences at a reasonable cost. The fear when it comes to local democracy is that the relationship between effectiveness and effi-

${ }^{1}$ The paper was first presented at the 2015 Annual Conference of the Comparative European Politics Specialist Group of the Political Studies Association "Toward a Broader Discipline: Russia, Europe and new Possibilities for the Study of Comparative European Politics", Lomonosov Moscow State University, November 19-20, 2015. 
ciency takes the form of a vicious cycle in which both terms would not so much oppose as reinforce themselves in a downward spiral.

One solution put forward by many scholars is to involve policy networks. Commonly defined as "sets of formal institutional and informal linkages between governmental and other actors structured around shared if endlessly negotiated beliefs and interests in public policy" [5. P. 426], networks are supposed to enhance the decision-making process contributing to both effectiveness and efficiency of democracy. Networks' involvement through formal and informal procedures has been particularly sustained at the local level especially when it comes to investment and infrastructure projects. However, after 20 years of their involvement we still doubt either better representation or performance of public action. On the contrary, we might wonder whether networks development was not detrimental to both effectiveness and efficiency of local democracy.

Accordingly, in this paper set several interconnected purposes:

$1 /$ to clearly distinguish efficiency and effectiveness and to show that the relationship between the two terms in not necessarily of opposition;

$2 /$ to expose the dangerous nature of political networks at the local level; and finally

3/ to highlight potential alternatives to political networks that may be considered both effective and efficient.

In the first part of this paper we thus define the terms democratic effectiveness and democratic efficiency and offer a rapid overview of the relevant literature. We set simple criteria allowing us to evaluate the local democracy in terms of both characteristics. We then bring our attention to the concept of policy networks which is considered by an important group of scholars as the best instrument of conciliation between democratic effectiveness and government effectiveness. By analyzing several examples of city infrastructure development projects, we question the networks legitimacy. Finally, the third part of the paper focuses on other tools which could potentially enhance both the effectiveness and the efficiency. Among them we will particularly focus on participative democracy concept and more precisely on voting systems enabling the expression of multiple preferences.

\section{Efficiency and effectivity at the local level, from confrontation to a vicious circle?}

\subsection{Efficiency vs effectivity: a troubled relationship}

Efficiency and democratic legitimacy are widely seen to be, if not mutually exclusive, at least entangled in a "troubled relationship" [6]. Dahl [3] highlighted this democratic dilemma, as a trade-off, between system effectiveness and citizen effectiveness: between "the ability of the citizens to exercise democratic control over the decisions" and "the capacity of the system to respond satisfactorily to the collective preferences of its citizens". Dahl believes that citizens are confronted with a choice between preserving their influence over their government or giving the political unit freedom to act more efficiently with the critical issues. Though, at the same time, Dahl considers efficiency an important condition for a democracy to be perceived as legitimate: "if a government is perceived as effective, its successes are likely to enhance the prestige of the authority patterns it embodies" [7. P. 149]. 
Likewise, Lipset [8] does not find any connection between legitimacy and efficiency of the system, but does argue that low productivity may affect government support even if it was established according to the highest democratic standard. Therefore, the relationship between efficiency and democratic effectivity, or legitimacy, is more complex and cannot be reduced to Dahl's trade-off.

Scharpf's input/output model is a perfect means to analyze the inter-relation between efficiency and effectiveness [9]. He breaks down the democratic legitimacy in a two-dimensional concept of input and output legitimacy. The input relates to participation of the citizens in the decision-making process in order to reflect the will of the people. As Scharpf states himself, the input concept corresponds to Lincoln's notion of the government $b y$ the people": "political choices are legitimate if and because they reflect the will of the people - that is, if they can be derived from the authentic preferences of the community members" [9. P. 6]. In turn, output legitimacy refers to the actual government's achievement of the goals set by the people. Accordingly, choices are legitimate if and because they effectively promote the common welfare of the constituency in question [9. P. 6]. It corresponds to Lincoln's "government for the people".

Balancing between output and input is more complex than a mere opposition and may produce four different outcomes: a democratic deficit, a deliberative surplus, a pro forma situation or the most desirable a synergy [10]. The democratic deficit occurs when a higher emphasis is put on performance than on democratic participation. An opposite outcome, the deliberative surplus, happens when a high emphasis on participation hampers the performance. Pro forma describes a system in which both performance and participation are low. Finally, synergy describes a situation in which both the input and the output are balanced [10. P. 29].

Table 1. Relationships between performance and democratic control

\begin{tabular}{|c|l|c|}
\hline \multirow{2}{*}{$\begin{array}{c}\text { Emphasis } \\
\text { on performance }\end{array}$} & \multicolumn{2}{|c|}{ Emphasis on democratic control } \\
\cline { 2 - 3 } High & High & Low \\
\hline Low & Synergy & Democratic deficit \\
\hline
\end{tabular}

Source: Andersen, J. Balancing Efficiency, Effectiveness and Democracy in organizing Inter-Municipal Partnerships: Conflicting Aims? Scandinavian Journal of Public Administration (SJPA) Vol 15, no 2 (2011), p. 29.

A third dimension, throughput [11], allows to explain how relationships between input and output produce the above-mentioned outcomes. Throughput constitutes an intermediary dimension and represents the policymaking processes through which decisions go from input to output. As Schmidt puts it: "throughput includes not only the workings of the decision-making processes as a whole - that they work efficiently and appropriately in accountable and transparent manner but also the intermediation processes through which citizens qua interests as opposed to qua voters have an influence" [11. P. 20].

In this perspective, we will equate the effectiveness of the local institutions to the input-legitimacy and the efficiency to the output-legitimacy. Though efficiency cannot entirely be reduced to the output concept of Scharpf and needs the more

\footnotetext{
${ }^{1}$ See The Gettysburg Address speech
} 
traditional economic approach. The output question cannot be limited to "the achievement of the common welfare" but should be the achievement of the common welfare at the lowest cost for the constituency. Ultimately, the capacity to optimize the resources determines the very achievement of the goals set especially at the local level where resources are more and more constrained.

\subsection{The challenge of efficiency and effectivity at the Local level}

While national politics are mostly focused on broad issues as employment, growth, health etc., the inputs at the local levels are less politicized and much more bread and butter. The citizen's preferences will revolve around everyday problems such as housing, traffic, infrastructure, waste management, schools, public order, etc. In return, these civic interests are extremely fragmented and thus quite difficult to synthesize and formalize. Alternatively, the output is more easily measurable at the local level than at the national level. The output of local democracy consists essentially in the delivery of services, goods, infrastructure to the citizens that form a local welfare. There is no expectation that local government resolves such issues as civil liberties, foreign policy, economic policy. And therefore, ideological cleavages, which determine policy with respect to these issues, play a minor role. We are not saying that politics and ideology are absent at the local level, they are very much at play on each issue, but they do not produce compact groups of organized preferences. A reflection of that can be found for instance in the number of local mayors without political affiliation in many countries ${ }^{1}$.

Even though local problems are of a basic nature comparing general national concerns, they are extremely acute. People's expectation from the local governments are higher and much more concrete. Their efficiency can be easily measured as they mostly deal with well-defined and time-framed objectives. For this reason, local institutions are often deemed to be a potential solution to the general crisis of democracy. However, both their input and output legitimacy have been declining in the past decades. Local democracy is thus faced with a paradox: they are overwhelmed with citizens' requests and expectations while at the same time seeing their effectivity and effectiveness challenged.

Input legitimacy. The problem of democratic effectiveness is even more critical for local institutions than it is for national ones. Among the many symptoms of this phenomenon, none is more representative than the sharp drop in citizens' participation as measured by the voters' turnout to local elections experienced in the last decades. For instance, in the USA and Eastern European countries turnout rates are dismal and well below the $50 \%$ threshold. Even more striking than the absolute levels is the gap between general/national and local elections turnout. In nearly all surveyed countries, the gap is higher than 20 points (Table 2). Such data suggest a specific legitimacy problem of local democracy going far beyond the problems experienced at the national level. As a result, local institutions do not effectively represent citizens' preferences which also affects the output legitimacy.

\footnotetext{
${ }^{1}$ In France, the interior ministry estimated in 2008 that 24000 mayors out of 36000 were without political affiliation: http://www.europe1.fr/politique/municipales-le-sans-etiquette-la-nouvelle-la-mode1708913
} 
Table 2. Turnout at local and national elections for selected countries

\begin{tabular}{|c|c|c|c|c|c|}
\hline & France & Italy & UK & Russia & USA \\
\hline $\begin{array}{c}\text { Local } \\
\text { election }\end{array}$ & $\begin{array}{c}52,36 \% \\
\text { (mayoral, } \\
2014)\end{array}$ & $\begin{array}{c}52,2 \% \\
\text { (regionals, } \\
2015)\end{array}$ & $\begin{array}{c}31,3 \% \\
\text { (mayoral, } \\
2012)\end{array}$ & $\begin{array}{c}21 \% \\
\text { (mayoral, } \\
\text { regional, } \\
2014)\end{array}$ & $\begin{array}{c}20,9 \% \\
\text { (local, aver- } \\
\text { age, 2011) }\end{array}$ \\
\hline National & $\begin{array}{c}80,35 \% \\
\text { (presidential, } \\
2012)\end{array}$ & $\begin{array}{c}75,19 \% \\
\text { (legislative, } \\
2013)\end{array}$ & $\begin{array}{c}66,1 \% \\
\text { (general, } \\
2015)\end{array}$ & $\begin{array}{c}65,25 \% \\
\text { (presidential, } \\
2012)\end{array}$ & $\begin{array}{c}36,4 \% \\
\text { (mid-terms, } \\
2014)\end{array}$ \\
\hline Gap & $27,99 \%$ & $22,99 \%$ & $34,8 \%$ & $44,25 \%$ & $15,5 \%$ \\
\hline
\end{tabular}

Output legitimacy. Alongside the drop-in input legitimacy local democracy is also facing several major challenges which have the potential to impair its efficiency. If the picture is less clear cut and homogeneous than for citizens' representation the threat is very real. First, local institutions around the globe face financial constraint associated with an increase in citizens' requests. Because of decentralization and subsidiarity principles the local level is tasked with more and more competencies while at the same time seeing its resources reduced due to the fiscal crisis gripping many countries. Secondly, the efficiency defined as the effective use of these resources is also a matter of contention in many countries such as Spain, France, Italy...Finally, the capacity of local institutions to push forward their agenda, namely in infrastructure projects also seems to be declining. Cities and regions face more and more sharp opposition when it comes to infrastructure projects which are at best delayed or even often cancelled with substantial financial losses (not in my backyard syndrome). This last aspect is directly linked to the drop-in input legitimacy: since local democracy is less effective, it is easier for groups of citizens to contest specific measure or projects on the ground precisely that they do not reflect their preferences.

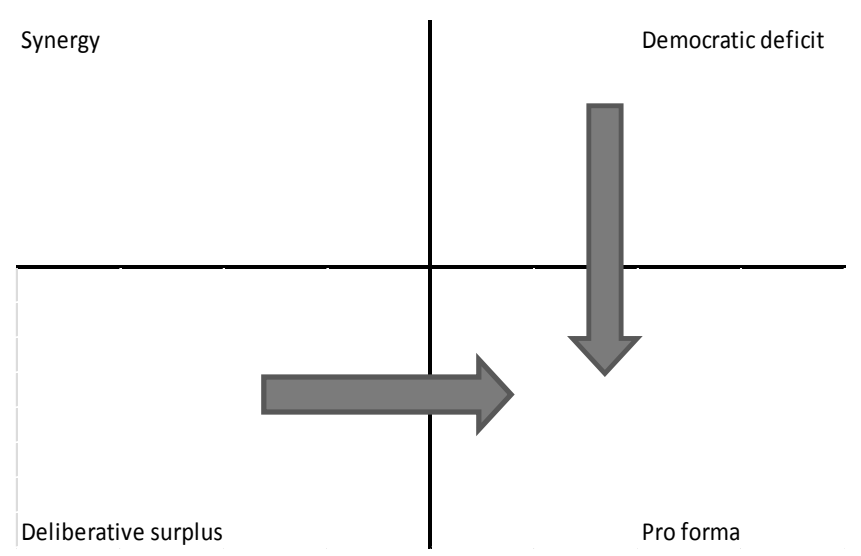

Figure 1. Relationship between efficiency and effectiveness

The relationship between efficiency and effectiveness ceases to be one of confrontation in form of democratic deficit or deliberative surplus (see Table 1). Ultimately input and output not only oppose but also determine each other. Each term is at the same time a potential obstacle but also a precondition of the other: the 
drop-in input legitimacy determines a similar drop in output legitimacy ultimately reinforcing citizens' disenchantment. Local democracy runs the risk of sliding into a pro forma situation is which neither efficiency nor effectiveness are satisfactory.

\section{Policy networks - a way to reconcile efficiency and effectivity at the local level?}

\subsection{Theoretical perspectives for policy networks influence at the local level}

The concept of policy networking represents an attempt to find a way to balance the tension between effectiveness and efficiency, between input legitimacy and output legitimacy. It is believed that networks, being understood as the assembly of various groups of interests, may provide consensus and therefore contribute to render the democracy more effective [12]. Other scholars claim they help to gather information, get access to needed resources and boost the implementation process [13;9]. All that should normally result in an increased output.

Policy networks can operate at all levels, local, national, global, but according to their supporters they are particularly suited to enhance local democracy and especially municipal democracy. Local networks are so popular that several terms, corresponding to new fields of research, have been coined. Among them network municipality [14; 15], or urban governance [16;17], both referring to a web of various types of institutions - local authorities, big private companies, interest groups' representatives, public and semi-public agencies, association, all working together to elaborate and implement various urban policies.

For Kenis and Raab [18], networks, first, could help the output issue as they represent the only possible form of government capable of embracing the complexity of contemporary society. Almost in unison Jordan and Schubert claim that networks are "the almost inevitable response to several developing characteristics of the contemporary public process" [19. P. 11]. They are often represented as the best way for the government to get access to dispersed resources thus enabling a more efficient goal-oriented public action and offering the possibility to decrease costs, to pool resources together and to create synergies [20. P. 259; 21. P. 37; 22].

According to the authors, which Klijn and Skelcher call the group of complementary conjectures, the networks also "oil the wheels of representative democracy" [23 P. 11] and make it more effective in both, input and output ways. On one hand, they help to reconcile the strategies and aims of different actors, which is improving the democratic input. On the other hand, they allow a well-balanced and co-coordinated process of policy making, which corresponds to governance output.

Even though networks have been attracting a sustained scientific and practical interest, there is neither clear definition of what constitutes a network nor clear descriptions of how they act in the real politics. In the wide sense, policy networks represent a knot of relations between government, business and civil society actors, which influence the policy making and implementation process $[24 ; 25 ; 26$. P. 39]. De Vries, on the other hand, sees four types of government-network interaction. First two depending on the nature of their interrelation: antagonism or congruence, and two others according to authority distribution: whether the government acts as a hierarchy or as a partner to policy networks [27. P. 96-97]. 
Table 3. Four Types of Interaction between Government and Societal Groups

\begin{tabular}{|c|c|c|c|}
\hline & \multicolumn{2}{|c|}{ Disparity of power and authority } \\
\hline & & Hierarchical & Horizontal \\
\hline \multirow{2}{*}{ 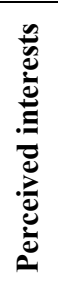 } & Antagonism & $\begin{array}{l}\text { A } \\
\text { Social groups as target groups } \\
\text { Government steers hierarchi- } \\
\text { cally }\end{array}$ & $\begin{array}{c}\text { B } \\
\text { Social groups as interest groups } \\
\text { Government mediates conflicts } \\
\text { of interest }\end{array}$ \\
\hline & Congruence & $\begin{array}{c}\mathbf{C} \\
\text { Social groups as customers } \\
\text { Government provides services }\end{array}$ & $\begin{array}{c}\text { D } \\
\text { Social groups as partners } \\
\text { Public governance: networks } \\
\text { and partnership }\end{array}$ \\
\hline
\end{tabular}

Source: de Vries, M. S. Public Participation in Policy Processes: Towards a Research Agenda. Administratie si Management Public, Bucharest, Romania. 2007, no 8. P. 150 (14-153)

Notwithstanding, most scholars limit their field of research to networks participating in the public policymaking process as government's partners (group D). More precisely in this perspective the government itself becomes one of the network's members along with other public, semi-public and private actors. The other types, however, are of a more conflict nature which obviously limits their efficiency in terms of political output. Even accepting that among the 4 groups the D is the most efficient, even scholars in favor of policy networks generally admit the concept has some shortcomings in terms of accountability and legitimacy [28. P. 8].

It is undeniable that policy networks, being free of any legal or administrative requirements and allowing different actors to flexibly pull resources together, are indeed very efficient in attaining their goals and satisfying their interests. While governments have very rigid structures, networks benefit from their flexibility: they easily change the number and the type of their members, split in several structures or, on the contrary, merge with other networks. Nonetheless, from the point of view of input legitimacy the interests and goals pursued by networks must always coincide with citizen's preferences. However, such interests and goals may not even be shared by all of networks' members.

In other words, the shared interest represents the principal condition of networks' positive contribution to the public governance. Borzel stresses that members of the networks "share a common interest with regard to a policy and ... exchange resources to pursue these shared interests" [20. P. 254]. At the same time, there is little theoretical knowledge about how the members attain this shared point of view in respect of any policy field. Anttiroiko points out that while networks must be based on solidarity, loyalty and reciprocity, collaboration of actors within the networks is also about bargaining and negotiation [29. P. 6]. Thus, the shared interest is not so much the initial aspiration of each member, but rather a compromise between them, the result of a negotiation in which the powerful actors naturally profit from their resources and influence. Sometimes this compromise is accepted by all members and, thus, represents a shared interest. But there also may be situations when this compromise is imposed by the more powerful members and only tolerated by the rest of them. Even more problematic is the fact that the network's shared interest does not necessarily coincide with the interest of all citizens concerned (their majority). The obvious problem of the democratic deficit in this situation becomes only greater when the networks are closed and citizens do not 
have possibility to participate in them or influence them [29. P. 15]. Even though almost all networks claim their open character, only few of them provide a truly open membership.

As demonstrated by below case-studies, the conflict between network's interests and public interest is a real problem. Many scholars suggest that opening the networks to citizen participation would be a viable solution. Though, the nonlimitation of the number and type of policy networks' members would make decision making process even more complicated and chaotic and would have a negative impact on the major advantages networks are supposed to bring: low transaction cost, balanced use of resources, strong consensus between the members, etc. In other words, reinforcing the democratic control over the networks by raising their representation ratio will most likely decrease their efficiency.

Indeed, policy networks seem not only problematic from the point of view of input legitimacy, but also in terms of output legitimacy. Their supporters suggest that co-operation of different political, social and economic actors constitutes a more effective governance than traditional vertical policy making [30]. But in practice, networks inclusion into public policy making often results in increased length and cost, while an organized, aim-oriented and prompt decision-making is the primary criteria of democratic government efficiency. However, in liberal democracies, where networks are most present, it is excessively slow and too formalistic. Formalism results in almost indefinite periods of decision making process on the national as well as on the local level. A slight deviation from prescribed rules and regulations is a pretext for its subsequent review, which can take even years. [31. P. 47].

\subsection{Policy networks and local decision-making process: case studies}

As case-studies we chose two examples of European local infrastructure/construction projects, both characterized by a high involvement of policy networks.

The triangle tower in Paris, France. The triangle tower, also known as pyramid tower, is a development project in Paris, consisting in creation of a skyscraper in the exhibition site of Park des Exposition. The project was presented by the Paris city hall in 2008. The tower is $180 \mathrm{~m}$ height and would be the third highest building in Paris after Eiffel and Montparnasse towers. It is a well-known fact that Paris population is strongly against the high-rise construction - more than $60 \%$ of Parisians support the city urbanism plan, which limits the constructions' height by 37 $\mathrm{m}$. Thus, to make the project possible there was a need for the city council to vote the modification of the plan, the approval of the plot's transfer from public property and the conditions of the easement. The gain for the city is not negligible. In exchange for the 80 years rent contract it would receive 2 million euros' annual fee. Since its announcement in 2008 the project has met serious opposition from citizens and several political parties. With time the disagreement among the members of the city council has become so evident, the administration of the city hall had to appeal council's decisions. Nevertheless, the city-hall staff was decisive to carry the project through all the barriers and make it finally happen. The question is: why is the mayor so keen to make this project a reality? 
The major who represents the population $-60 \%$ of which are against this kind of projects, whose citizens are posting protests via internet and in a state having already introduced the regulation limiting the high-rise construction in Paris,

The decision-making process in respect of the Triangle Tower involved two types of networks: those against the construction, and those, apparently much more powerful, - in favor of it. Our goal is to understand whether they have contributed to a more effective and efficient way of how local government has dealt with the project. The open network, mostly represented by the citizens' association "Against the triangle tower" (http:/www.contrelatourtriangle.com/), was sharing, indeed, the public interest (high input legitimacy), but was not capable of stopping the project (low output legitimacy). On the contrary, the shadow network, consisting of city officials, business representatives, the developer of the project UnibailRodamco, architects etc., all of them operating behind the city administration, was much more successful in achieving its goal. However, at any condition it can be regarded as the promoter of democracy effectiveness. First, it is of the most closed nature, second, its interest is in contradiction with the general interest of the population. Although, with the help of the administration, it was effective in achieving its personal goals.

The triangle tower case makes it evident, that networks do not always contribute to democratic effectiveness (political input) and even less to governance efficiency, or political output. Not only did the project not reflect citizens' preferences but it has mobilized the city's resources for nearly seven years. Seven years of confrontation of the various interests, of appeals to the votes, changes in the urbanism plan, and the construction still has not begun.

Europoint Brno, Czech Republic. The construction of the new railways station in Brno, also known as Europoint Brno, has become one of the most controversial projects of the Czech Republic. Brno, the second largest city of the country, is the crossing point of the two major railways corridors. One goes from the Baltic Sea to Italy, the other connects the Northern sea countries to the Mediterranean. Brno station thus may become the crucial railway junction between the two roads. The infrastructure of the existing station, however, is outdated and cannot accommodate the project of such scale. Moreover, it is already on the borderline of its capacity to serve present needs.

Even though the modernization of the existing facilities is possible financially as the European Union has allocated relevant funds for this purpose, it still has not started. This project is of great significance for the city and for the South Moravia region, yet, since its announcement back in 2002 it stagnates due to an unprecedented opposition from the civil networks. Five government institutions are working today on the project trying to find some agreement between them and the activists (mostly represented by Brno active citizen's association “Žít Brno"). For more than ten years the city-hall has been trying to persuade all parties to agree on the project, which most of the population approve and awaits, but no consensus has been reached so far. The discussion about it is literally monopolized by the networks, which block the modernization by contesting some minor details, such as the new station position (the argument is about some $500-\mathrm{m}$ difference), its nearness to the river bank or the need for modification of the existing tram's itinerary. To overcome this populist discourse, the city hall has decided to mobilize all citi- 
zens concerned (via the specially dedicated europointbrno.cz) and conduct the referendum. There are today three possible solutions for the project: the first two represents the alternatives of station's placement, the third one is called Zeroalternative, meaning no new station for Brno city.

The projects of Triangle Tower and Europoint Brno are sad examples of how the networks can reduce both democratic input and output by highjacking the political agenda. They claim to strengthen the democratic control, but very often, as in case of Europoint Brno, they just prevent the local institutions from serving the interests of the majority. The networks' populism becomes a substantial problem for both democracy efficiency and effectiveness. Rather than enforcing citizens' preferences, local governments often waste public resources and time negotiating with networks as in the Europoint Brno case; or, even worse, use these resources in favor of the networks' interests as was the case of the Triangle tower project.

\section{Alternatives to network governance for effective local democracy}

\subsection{Contemporary direct democracy instruments}

Among the many scholars criticizing the governance networks [32; 33] some suggest that direct participatory democracy can be a way to overcome the system's shortcomings and reconcile efficiency and effectiveness at the local level $[34 ; 35]$. As more and more citizens are under the impression that laws do not reflect their preferences but those of pressure groups, direct participatory instruments appear to be a proper solution to overcome the networks' opposition and improve the citizens' involvement in the policy making process. We will study several of these mechanisms and analyze their impact on both input and output legitimacy.

Popular referendums (Switzerland). Referendums, according to the Swiss example, are viewed by many as one of the main answer to the crisis of local and national democracy [36]. In Switzerland the referendums can be: a) mandatory, when it concerns infrastructure financing; b) optional, which means every citizen can gather 50.000 signatures in order to hold a referendum on any particular law; c) constructive (in Bern and Zurich cantons), which means there is no option to outright oppose a law but to offer an alternative on some disputed aspects) and d) the most famous popular initiative referendums which allow citizens to propose new legislation at the national and local level.

According to popular referendums' supporters, they increase both the input legitimacy (the citizens decide directly) as well as the output (the risk of contestation is reduced as the result corresponds to citizens' preferences). Though, the issue is more complex than it seems. Many questions remain open in terms of their input, or democratic effectiveness. First, referendums may become just another instrument in hands of pressure groups. Quite often the initiatives come from networks and not from individual citizens. Second, the law projects are prepared by professional lawyers and specialists in the field of a given legislation, and their expensive work is mostly financed by powerful opinion groups. Third, to bring the project to the referendum vote, an important campaign should be organized requiring an organization if not financial means. But the main limitation, especially for the use of referendums at the local level, is that the answers are binary (yes/no) and based on the simple majority principle. At the end, the answer might not even reflect the 
preferences of the real majority but only of a sizeable and motivated minority. And the binary answers do not allow to capture the nuances and multiplicity of these preferences. That explains why over time different answers have been given to similar questions (for example, Denmark on the Maastricht Treaty, Ireland on the Nice Treaty and the Lisbon Treaty).

Output, or democratic efficiency of the referendums fail to convince precisely because of the shortcomings mentioned above. The inconsistency of vote results may bring a great deal of inefficiency into the system. The referendum on Zurich metro is a good example. Twice, in 1960 and 1973, voters rejected the idea of an underground metro delaying the construction of a much-needed transportation network. Only 20 years after the first vote an alternative solution of a surface network was approved by the referendum of 1981. It does not seem that referendums in this case greatly helped a more rapid discovery of citizens' preferences and an enhanced output. It took years and many costly studies to finally come up with a solution to a pressing problem, that might have been found earlier.

Conseils de quartiers (France). Citizens' councils were introduced in in 2002 France to allow people's participation in the elaboration and implementation of various projects promoted by the city. The main objective of their establishment was to encourage participatory democracy mechanisms in the urban governance. However, this attempt to foster direct democracy in French municipalities does not really convince. Tomas Kirszbaum sees the major problem in the abandonment of the initial idea of the citizens' council, which consisted in co-decision making between the city council and the citizens [37]. However, the councils, as they exist today, do not intervene at the stage of decision making. Their implementation can be mostly observed at the phase of decision implementation. Consequently, they do not impact the democratic input stage and, thus, do not contribute to the democracy effectiveness. Nor do they help local democracy to become more efficient, as their late involvement in the political process only worsens the bureaucratic lengthiness of the urban management.

Opinion polls. Conventional opinion polls are used more and more to test citizens' preferences on a project or local orientations. Though, resorting to conventional polling at the local level pose many problems. First, large opinion polls entail no real deliberation [38] - the responses given by the respondents are intrinsically non-attitudes [39] or at the least minimal attitude [40]. As Fishkinh and Lushkin put it "the opinions it tallies are not informed by any thorough airing or consideration of alternative views" [34: 287]. Then the use of polls at the local level may be even more problematic in small or non-homogeneous constituency. In many cases the sampling might not be truly representative. Thus, opinion polls might have some value to determine citizens' preferences only if they use a large sample, being possible in sufficiently big cities and regions.

Citizen surveys. Citizen surveys aim to overcome the problem of the representation sample. In this case, the survey is open to all or at least most citizens in each local constituency. According to Nayyar-Stone and Hatry [35. P.1] "surveys of citizens (and of the customers of public services) are often the only technique available to obtain accurate data for certain outcomes (results) of services". The goal stated here is clearly to enhance the output legitimacy. Citizens' surveys are widely used in many countries. However, they are not without flaws either as their 
performance heavily depends on the data quality (how the survey is conducted) and the interpretation of results (how the data is converted into useable information). Citizens surveys suit mostly small constituencies while opinion polls are more appropriate, as has been said already, in exploring expectations in communities with large populations, Otherwise, they share a lot of common insufficiencies: lack of deliberation, question quality, binary answers and the problem of thin majority at the local level.

Deliberative polls. As an alternative to conventional polling, Fishkin [38] defends the idea of deliberative polling. Within the frame of this approach, the randomly selected sample of citizens should not just answer a question or a set of questions but engage in a deliberation to enable a process of informed opinion change [34: 289]. Deliberative polls have been used in several countries recently as for instance in Denmark before the 2000 referendum on euro adoption, in Australia, UK or the USA.

Deliberative polls by their very nature focus more on the input legitimacy. The idea, however interesting, again finds its limitation in the binary character of the answers given and the problem of majority. Besides that, the sample can always be subject to criticism in terms of representation and, thus, its democratic legitimacy can always be questioned by citizens left out of the poll.

\subsection{Digital democracy and multiple citizens' preferences}

The combination of new technologies and of recent development of multiple preference models can produce an interesting instrument to overcome the shortcomings of classical direct democracy mechanisms, however, preserving the idea that a greater citizen's participation is beneficial to local government both in terms of its effectiveness and efficiency.

Technological revolution and internet proliferation were a popular topic of political science research at the start of the millennium. Many scholars believed the use of these technologies could help bridge the gap between citizens and governments. Internet was meant to foster citizens' participation and ultimately democracy [41]. Though, today one is forced to acknowledge that most of these expectations have been deluded. To quote Matthew Hindman [42], digital democracy has been so far nothing but a myth.

Though, the combination of IT and rethinking of the voting process based on multiple preferences expressions might prove an interesting lead. Expression by citizens' multiple preferences helps to overcome many of the problems participative democracy is facing nowadays and offers a possibility to go beyond the binary and simplistic character of the instruments discussed above. To take an example, citizen $\mathrm{A}$ is against some project, while citizen B in is favor, but there are also citizens' $\mathrm{C}$ and $\mathrm{D}$ who are in favor, but $\mathrm{C}$ is opposed to its proposed location and D is opposing its architectural presentation. So far, no instruments can factor these nuances and the complexity of citizens' preferences at the local level. In our opinion, this failure is the main explanation of the drop local democracy's effectiveness and efficiency. The expression of multiple preferences during polls and referendums could allow factoring this complexity into an optimum decision, while the new technology can be the means of making such "multipolar" vote possible. This field of research, based 
on the results of behavioral and game theory is still at its early stage, but there are already some serious attempts to bring this study into practice. One of them was developed by Carl Janacek in the Czech Republic and successfully tested for the local administration of infrastructure projects.

Carl Janáček Democracie 2.1. model (http://news.d21.me/cs/) is at the center of contemporary debate and offers an effective way to resolve the conflict between democratic values and decision-making efficiency. The model is based on the simple assumption that the political decisions, taken on the base of a single voting preference are more likely to fail the citizens' expectations than a decision which considers their multiple preferences. To illustrate the operation of his model, Janáček offers a survey of eight firegners trying to choose restaurant for their dinner (Figure 3). Traditional electoral system gives each of us the right to choose just one of the alternatives. In some configurations, the result of such vote may in fact satisfy only a minority of the voters. In Janacek's example only 2 out of 8 dinner companion are satisfied with the choice in one "pro" vote configuration (Figure 3.a). At the same time, Janáček's simulation shows that if you give each voter two votes "pro," i.e. the opportunity to choose two acceptable options, the number of satisfied persons will grow (Figure 3.b). But truly revolutionary approach will consist in giving each of us the possibility to vote "pro" for two acceptable options and one "contra" for one unacceptable option. According to the simulation, it will allow to transform voting dissatisfaction into neutrality (Figure 3.c).

3.a

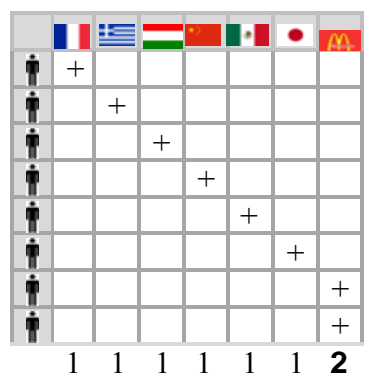

Satisfied: 2

Dissatisfied: 6 3.b

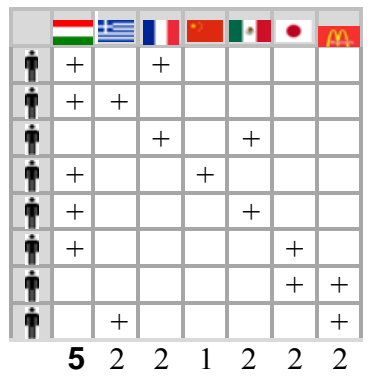

Satisfied: 5

Dissatisfied: 3 3.c

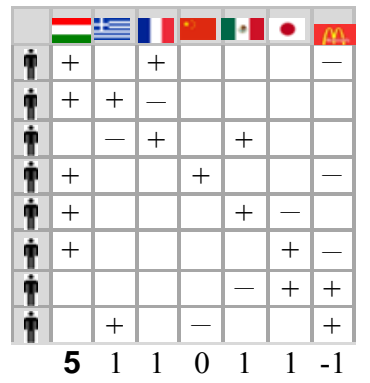

Satisfied: 5

Neutral: 3

Dissatisfied: 0

Figure 3. Demonstration of the action of Janáček's model

Janáček offers us an updated version of participative democracy, which today becomes possible by the method of decision-making through the development of technological support - it is enough to have the desired application on your computer or phone. This model seems particularly suitable for the local level and has been successfully tested in the Czech town of Ričany to enable citizens to decide on local investments and in New-York, in cooperation with Stanford University to decide on public lighting and sidewalks. 


\section{Conclusions}

On one hand, local democracies are largely viewed by citizens as one of the answers to the broader crisis of democracy. The Citizens are more likely to trust local institutions and most them wishes the powers of these institutions to be increased. But, on the other hand, local democracy is particularly affected by the legitimacy crisis, as the dismal voter turnout rates exemplify. This drop in the effectiveness or input legitimacy has, in turn, a sizeable impact on efficiency at the local level. This shows how crucial the relationship between efficiency and effectiveness is for local democracy. The risk is a vicious cycle in which efficiency and effectiveness, in their interdependency, are reinforcing each other in a downward spiral.

For many authors a viable solution to this problem is represented by policy networks, which have become in recent years a very popular concept in political analysis literature. Networks are not only sees as a form of government able to embrace the complexity of contemporary policymaking also as the best suited method of administration at the local level. Nevertheless, this article proves the contrary showing that networks at the local level do not have any decisive impact on either term of the equation. On the contrary, in some cases they are detrimental and reinforce the loss of both efficiency and effectiveness.

Alternatives can be found in participatory democracy instruments such as referendums, surveys or polls. Although they all bring some advantages to the political process, they fail to solve the issue of reconciling input and output legitimacy. More sophisticated methods are needed. Some of them might be found in new technologies enabling citizens to express multiple preferences and even negative preferences. The combination of modern IT-instruments and these models might finally constitute a breakthrough in order the enhance citizens' participation and decision making efficiency at the local level. In the end of this paper we develop one of such models, Democracie 2.1, and show that their implementation at the local level may have a superior contribution to democratic input and output comparing to other instruments of participative democracy. Even though Democracie 2.1 is just one case, the experience of its implementation in several municipalities must be seriously taken into consideration by researchers so that someday it may be translated into a full-scale theory and, thus, become a general approach to public administration at the local level.

\section{References}

1. Crozier, M.J. \& Huntington,S.P. \& Watanuki, J. (1975) The Crisis of Democracy. Report on the Governability of Democracies to the Trilateral Commission. New York, NY: New York University Press.

2. Raschke, J. (1993) Die Grunen. Vie sie wurden, was sie sind. Cologne: Bund. (In German).

3. Dahl, R. (1994) A Democratic Dilemma: System Effectiveness versus Citizen Participation. Political Science Quarterly. 109(1). pp. 23-34. DOI: 10.2307/2151659

4. Courtois, G. (2015) Comment les Français veulent réparer la démocratie [How the French want to repair democracy]. Le monde. 21st April. [Online] Available from: http://www.lemonde.fr/politique/article/2014/04/21/les-francais-reclament-davantage-de-proximiteavec-leurs-elus_4404638_823448.html. (Accessed: 18th October 2016).

5. Rhodes, R.A.W. (2008) Policy Network Analysis. In: Goodin, R., Moran, M. \& Rein, M. (eds) The Oxford Handbook of Public Policy. Oxford: Oxford University Press. pp. 425-447. 
6. Blatter, J. (2009) Efficiency and Democracy. Reconstructing the Foundations and Transformations of a Troubled Relationship. In: Blühdorn, I. (ed.) In Search of Legitimacy. Policy Making in Europe and the Challenge. Oplanden/Farmington Hills, MI: Budrich Publishers. pp. 51-71.

7. Dahl, R. (1971) Polyarchy: Participation and Opposition. New Haven: Yale University Press.

8. Lipset, S.M. (1959) Some Social Requisites of Democracy: Economic Development and Political Legitimacy. The American Political Science Review. 53(1). pp. 69-105. DOI: 10.2307/1951731

9. Scharpf, F.W. (1999) Governing in Europe: Effective and Democratic? Oxford: Oxford University Press.

10. Andersen, J. (2011) Balancing Efficiency, Effectiveness and Democracy in organizing InterMunicipal Partnerships: Conflicting Aims? Scandinavian Journal of Public Administration (SJPA). 15(2). pp. 25-46.

11. Schmidt, V.A. (2010) Democracy and Legitimacy in the European Union Revisited: Input, Output and 'Throughput'. KFG Paper Series. 21st November. [Online] Available from: http://userpage.fuberlin.de/kfgeu/kfgwp/wpseries/WorkingPaperKFG_21.pdf. (Accessed: 18th October 2016).

12. Marin, B. \& Mayntz, R. (eds) (1991) Policy Networks. Empirical Evidence and Theoretical Considerations. Boulder, Colo.: Westview.

13. Kooiman, J. (ed.) (1993) Modern Governance. New Government - Society Interactions. London: Sage.

14. Airaksinen, J. \& Haveri, A. (2003) Networks and Hierarchies in Inter-municipal Cooperation - Are Networks Really Light and Flexible and Hierarchies Sticky and Rigid? Paper presented at the conference of European Group of Public Administration, Lisbon, September.

15. Toikka, A. (2011) Governance Theory as as Framework for Empirical Research - a Case Study on Local Environmental Policy-Making in Helsinki, Finland. PhD Diss. Helsinki.

16. Le Gales, P. (1995) Du gouvernement des villes a la gouvernance urbaine [From city government to urban governance]. Revue française de science politique. 45(1). pp. 57-95.

17. Pinson, G. (1999) Projets urbains, acteurs économiques et construction des territoires politiques : deux scenario [Urban projects, economic actors and construction of political territories: two scenarios.]. European Cities in Transformation. Proc. of the Colloquium. Paris, European Urban Reseurch Association. October 22-23.

18. Kenis, P. \& Raab, J. (2003) What Do Policy Networks Do? Paper presented at the Conference on Democratic Network Governance. May 22-23, 2003. Copenhagen, Denmark.

19. Jordan, G. \& Schubert, K. (1992) A Preliminary Ordering of Policy Network Labels. European Journal of Political Research. 21(1-2). pp. 7-27. DOI: 10.1111/j.1475-6765.1992.tb00286.x

20. Börzel, T.A. (1998) Organizing Babylon - On the Different Conceptions of Policy Networks. Public Administration. 76(2). pp. 253-273. DOI: 10.1111/1467-9299.00100

21. Rhodes Rod, A.W. (1997) Understanding Governance. Policy Networks, Governance, Reflexivity and Accountability. Buckinngham Philadelphia: Open University Press.

22. Thompson, G.F. (2003). Between Hierarchies and Markets. The Logic and Limits of Network Forms of Organization. Oxford: Oxford University Press.

23. Klijn, E.-H. \& Skelcher, C. (2008) Democracy and Governance. Networks: Compatible or not? Four Conjectures and their Implications for Theory and Practice. Public Administration. 85(3). pp. 587-608. DOI: 10.1111/j.1467-9299.2007.00662.x

24. Knoke, D. (1990) Political Networks. The structures perspective. Cambrige: Cambrige University Press.

25. Kickert, W.J.M. (ed.) (1997) Public Management and Administrative Reform in Western Europe. Cheltenham: Edward Elgar Publishing.

26. Le Gales, P. \& Thatcher, M. (1995) Les réseaux de politique publique: débat autour des policy network [Public Policy Networks: Policy Network Debate]. Paris: L'Harmattan.

27. De Vries, M.S. (2007) Public Participation in Policy Processes: Towards a Research Agenda. Administrație Şi Management Public. 8. pp. 144-153.

28. Besussi, E. (2006) Policy Networks: Conceptual Developments and their European Applications. UCL Working Paper Series. 102. [Online] Available from: https://www.bartlett.ucl.ac.uk/casa/pdf/paper102.pdf. (Accessed: 18th October 2016).

29. Anttiroiko, A.-V. (2006) Towards Network Democracy? Paper presented at the seminar "Politics on the Internet: New Forms and Media for Political Action". November 24-25, 2005. University

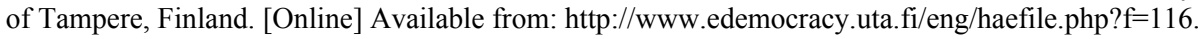
(Accessed: 18th October 2016). 
30. Simon, H. (1973) The Structure of Ill-Structured problems. Artificial Intelligence. 4. pp. 181201.

31. Bordovskikh, A. \& Boussier, R. (2015) Decision-Making Process in Contemporary Democracies. In: Tsygankov, A. et al. Democracies XXI: A Paradigm Shift. Moscow: ISERP Foundation. pp. $38-65$.

32. Lowndes, V. (2001) Rescuing Aunt Sally: Taking institutional theory seriously in urban politics. Urban Studies. 38(11). pp. 1953-1971. DOi: 10.1080/00420980120080871

Anastasia N. Bordovskikh. Moscow University Lomonossov (Moscow, Russian Federation)

E-mail: bordovskikh@spa.msu.ru

DOI: $10.17223 / 1998863 X / 40 / 20$

Raphael François Fréderic Boussier. School of Public Administration, Moscow University Lomonossov (Moscow, Russian Federation)

DOI: $10.17223 / 1998863 X / 40 / 20$

\section{AN EFFICIENT AND EFFECTIVE DEMOCRACY AT THE LOCAL LEVEL: NEW ALTERNATIVES TO POLICY NETWORKS}

Key words: democracy effectiveness and efficiency, democratic input and output, policy networks, participatory democracy, local democracy, decision-making process, preferential voting, infrastructure governance.

The tension between ideological fundaments of democracy and its effectiveness as political regime is an old dilemma dating back to the emergence of the concept itself and reiterating through the history. Today, the tension between democracy, legitimacy, and efficiency is back on the forefront as most western democracies are mired in manifold crisis resulting in an eroded support for the concept at home and abroad. Both the effectiveness of interest representation and democratic government effectiveness as public administration are questioned. Among the many attempts to resolve this tension, policy networks are believed by many scholars to be one of the most suitable solutions to revitalize democracy, especially at the local/municipal levels. Though, while almost everyone agrees on their relative efficiency in dealing with the challenges of the new century, a considerable number of scholars warn against their lack of democratic legitimacy, of civil control and of accountability. In this paper, we do not only share this position, but also question the networks' commonly believed efficiency focusing on the micro/local level. In the first part of the article we give a clear definition of democratic effectiveness and efficiency and explain their interdependence. The analysis of local democracy effectiveness is based on the "input - output" model, which partially refers to Andersson's (Andersson, J.) and Sharpf's (Sharpf, F.) theories. Based on this model the second part of the paper considers several recent case studies of local infrastructure projects, involving networks of some sorts, in several European countries. This empirical study tends to support our view that networks are far from enhancing efficiency and can also undermine the legitimacy of the local decision making process. In recent years, public administration on the local level mostly intend to satisfy the network needs instead of satisfying those of the civil population majority. In other words, by violating a normal interest representation scheme, policy networks bring considerable negative impact on both democratic effectiveness and efficiency. In our article, we pay attention to the problem of the fundamental legitimacy of policy networks' participation in political process. The absence of any legal base for their activity brings the question of networks' legitimacy even when their interests formally coincide with those of the majority. As an alternative, we explore new ways how to involve citizens in the decision-making process restoring their faith in local institutions while in fine increasing the overall efficiency of the local politics. Among them, municipal councils, opinion polls, civil initiatives referendums, electronic democracy. Their general aim is to bring back the civil faith in local institutions and improve their effectiveness in resolving vital challenges of the population. New sophisticated forms of direct democracy, drawing inspiration from game theory and behavioral economy and enabling the citizens to simply rank and express preferences seem the most promising. 